\title{
Optimization of Some Parameters on the Low Efficiency of Solvent Extraction of Uranium with Alamine 336
}

\section{ABDOUL-RACHID CHAÏBOU YACOUBA ${ }^{1 *}$, SALMANA LAOUALI IBRAHIM ${ }^{2}$, ABDOUL RAZAK MOUMOUNI WAGE ${ }^{2}$ and IBRAHIM NATATOU ${ }^{1,2}$}

\author{
'Department of Chemistry, Faculty of Sciences and Techniques, Agadez University, \\ P.O.B. 199, Agadez, Niger. \\ ${ }^{2}$ Valorization of Materials, Water, and Environment Laboratory, Faculty of Sciences and Techniques, \\ Abdou Moumouni University, P.O.B. 10662, Niamey, Niger. \\ *Corresponding author E-mail: arachidchaibou@gmail.com
}

http://dx.doi.org/10.13005/ojc/370129

(Received: December 26, 2020; Accepted: January 27, 2021)

\section{ABSTRACT}

Solvent extraction of uranium from sulfate liquor acid ore with Alamine 336 from two suppliers has been studied. The influence of various parameters, such as sulfuric acid concentration on uranium bearing solutions, concentration of Alamine 336, and concentration of uranium was investigated. The decrease of uranium efficiency extraction at the plant was caused by the degradation of the organic phase. Degradation caused by the presence of vanadium in the uranium ore. Two theoretical stages could efficiency extract more than $90 \%$ of uranium from a solution containing $3881 \mathrm{mg} / \mathrm{L}$ at O/A ratio of $1.5: 1$. At the range of sulfuric acid concentration of $0.1 \mathrm{M}$ to $0.2 \mathrm{M}$, Uranium efficiency was enhanced from $89 \%$ to 92 at the 1 st contact and from $18 \%$ to $20 \%$ at the second contact. At this range of concentration, the $\mathrm{UO}_{2}\left(\mathrm{SO}_{4}\right)_{2}{ }_{2}$ - species predominate. For sulfuric acid concentrations over $0.2 \mathrm{M}$ the uranium efficiency decreased due to the presence of $\mathrm{UO}_{2}\left(\mathrm{SO}_{4}\right)_{2}{ }_{2}$ and $\mathrm{UO}_{2}\left(\mathrm{SO}_{4}\right)_{3}{ }^{4-}$ species. Improving volume percentage of Alamine 336 in organic phase enhanced the uranium efficiency to $99 \%$.

Keywords: Optimization, Solvent extraction, Uranium, Alamine 336, Niger plant.

\section{INTRODUCTION}

The production of nuclear fuel at a competitive price compared with other sources of energy is a permanent concern of the nuclear industry.

The solution of this situation must necessarily go through the research and exploitation of new uranium deposits, but also through the mastery of nuclear technology to design very safe, reliable and environment-friendly nuclear power plants.

The Republic of Niger is located in West Africa with an area of $1.267 .000 \mathrm{~km}^{2}$ annually produces more than 3.000 tons of uranium. In 2016, national production was 3.479 tones. So, it has

This is an Open Access article licensed under a Creative Commons license: Attribution 4.0 International (CC- BY). Published by Oriental Scientific Publishing Company @ 2018

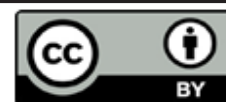


risen to the $4^{\text {th }}$ position among uranium producing countries in the world ${ }^{1}$. However, it remains one of the poorest countries with a GDP, which ranks it $143^{\text {rd }}$ in the world on 195. Uranium constitutes the country's main source of income in the industrial field.

The uranium sites discovered in Niger are located in the northwestern part of the country, on the western border of the Airr massif. The main mining sites in exploitation are the Arlit site, the Akouta site and the Azelik site respectively exploited by SOMAÏR, COMINAK and CNNC (chinese).

ORANO (formerly known as AREVA) is the majority shareholder of SOMAÏR and COMINAK ${ }^{2}$. At the Akouta Mining Company, uranium is found in the Guezouman sandstone formations, whose mineralized can vary from 1 to $15 \mathrm{~m}$ with an ore concentration between $0.2 \%$ and $0.6 \%$ in uranium. The sterile cover is $250 \mathrm{~m}$. These companies purify and concentrate uranium, which the final products are respectively sodium diuranate $\left(\mathrm{Na}_{2} \mathrm{U}_{2} \mathrm{O}_{7}\right)$ and magnesium diuranate $\left(\mathrm{MgU}_{2} \mathrm{O}_{7}\right)$.

Generally confined in uranium ore, vanadium, zirconium and molybdenum are troublesome elements for the Republic of Niger, which prefers to valorize uranium.

These uranium companies use liquid-liquid extraction as the process to recover uranium. Tertiary amines such as Alamine 336 are widely used in the extraction of uranium.

Over the extraction cycles, the solvent loses its efficiency to extract uranium. This solvent is a mixture of Alamine 336 as extractant, isotridecanol as alcoholic modifier and kerosene as diluent. Some studies on the chemical mechanism of solvent degradation ${ }^{3-5}$ proved that the conversion of tri-noctylamine were responsible of the low uranium rate recovering. Indeed, the presence of vanadium in the uranium bearing solutions on polyvanadates forms 6 was majority responsible for that modification of Alamine 336. They also reported that the presence of other parameters like molecular dioxygen, chromium influenced the solvent degradation.

In this regard, we focused on the solvent extraction of uranium from uranium bearing solutions of Cominak plant. The effects of various parameters like contact number, ratio between organic and aqueous phase, uranium concentration, Alamine 336 concentration and sulfuric acid concentration were investigated in order to extract efficiency uranium.

\section{MATERIALS AND METHODS}

\section{The reactants}

Alamine 336 (industrial grade, Cognis and BASF) was an anionic extractant with a flashpoint of $179^{\circ} \mathrm{C}$. Kerosene (industrial grade, Total) was used as diluent Table 1 shown some properties. Isotridecanol (analytical grade, VWR) was used to avoid the formation of the third phase with a flashpoint of $122.5^{\circ} \mathrm{C}$. The mixture of these reagents formed the organic phase.

Table 1: Kerosene properties

\begin{tabular}{cc}
\hline Density $\left(\mathrm{g} / \mathrm{cm}^{3}\right)$ & 0.788 \\
Viscosity $(\mathrm{cP})$ & 1.64 \\
Solubility in water at $20^{\circ} \mathrm{C}$ & - \\
Dielectric constant & 1.8 \\
Boiling point $\left({ }^{\circ} \mathrm{C}\right)$ & 150 \\
Molecular weight $(\mathrm{g} / \mathrm{mol})$ & 170.34 \\
Flash point $\left({ }^{\circ} \mathrm{C}\right)$ & 54 \\
\hline
\end{tabular}

Tri-octyl-phosphine oxide (TOPO) was a solvating or neutral extractant (purity $>99 \%$, Merck), sulfuric acid (purity 95\%, VWR), nitric acid (purity $65 \%$, VWR), sodium fluoride (analytical grade, VWR) were used to prepare organic phase to re-extract uranium from aqueous samples. Pyridin (analytical grade, VWR), dibenzoylmethane (purity $>99 \%$, Merck) were used to dose uranium.

The aqueous phases were prepared from uranium-bearing solutions, Fig.1 those last were obtained from the leaching of uranium ores process.

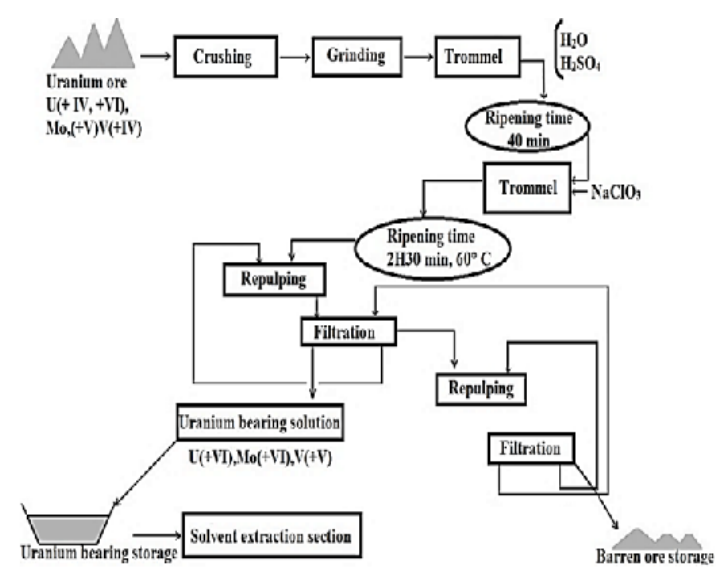

Fig.1. Uranium solvent extraction process 
The solutions had a free acidity $\left(\mathrm{H}^{+}\right)$of 10 to $22 \mathrm{~g} / \mathrm{L}$ and Table 2 shown the composition of some parameters. The experimental temperature was maintained at $30^{\circ} \mathrm{C}$.

Table 2: Composition of uranium-bearing solutions sample

\begin{tabular}{cc}
\hline Sample & Concentration \\
\hline Uranium $(\mathrm{mg} / \mathrm{L})$ & 3698 \\
Molybdenum $(\mathrm{mg} / \mathrm{L})$ & 52 \\
Vanadium $(\mathrm{mg} / \mathrm{L})$ & 2423 \\
Zirconium $(\mathrm{mg} / \mathrm{L})$ & 20 \\
Iron $(\mathrm{mg} / \mathrm{L})$ & 465 \\
$\mathrm{pH}$ & 1 \\
Redox potential $(\mathrm{mV})$ & 496 \\
\hline
\end{tabular}

\section{Extraction procedure}

The extraction process was done in mixersettler. The shaking was set at $700 \mathrm{rpm}$ with a Heidolph brand agitator. The $\mathrm{pH}$ was determined with Knick pH-meter 766-calimatic device and the redox with Hanna HI $98240 \mathrm{pH} / \mathrm{ORP}$ meters device. In the mixer-settler $100 \mathrm{~mL}$ of aqueous phase containing the metal and $100 \mathrm{~mL}$ of organic phase containing Alamine 336 were brought into $2 \mathrm{~min}$, sufficient time for the transfer of metal from one phase to the other. At the end of the extraction, the two phases were separated by decantation.

The analysis of the aqueous samples was done after an adequate dilution. The test samples depended on the uranium concentration in the aqueous solutions (directly for weak concentrations and by dilution for high concentrations).

In pill jar containers of $60 \mathrm{~mL}$ according to the test samples, the following additions were made: solution of $\mathrm{HNO}_{3}$ at $10 \%$; solution of $\mathrm{NaF}$ as oxidant; solution of TOPO as extractant. The whole were stirred for 10 minutes. After decantation, the organic phase (TOPO) was carefully removed. It was taken using a diluting device. The setting was of $1 \mathrm{~mL}$ of the organic phase for $3 \mathrm{~mL}$ of the DBM solution. The formation of a U-DBM complex of yellow coloring in pyridine medium was obtained.

The uranium was analyzed with a Varian Cary 50 UV-Vis spectrophotometer at $405 \mathrm{~nm}$.

The determination of molybdenum in the aqueous phase was carried out directly after an adequate dilution with solution of $\mathrm{Al}\left(\mathrm{NO}_{3}\right)_{3}$, solution of $\mathrm{KCl}$, and solution of $\mathrm{HNO}_{3}$. Molybdenum was analyzed using a Varian AAFS240 atomic absorption spectrophotometer equipped with an acetylenenitrous oxide burner at $313 \mathrm{~nm}$.

The distribution coefficient relation of Eq. (1) and the extraction efficiency percentage relation of Eq. (2) were respectively determined by the following formulas:

$$
\begin{aligned}
& \mathrm{D}=[\mathrm{M}]_{\text {org }} /[\mathrm{M}]_{\text {aq }} \\
& \mathrm{E}(\%)=\left(\mathrm{D} / \mathrm{D}+\left(\mathrm{V}_{\mathrm{aq}} / \mathrm{V}_{\text {org }}\right)\right) \times 100 \\
& \quad[\mathrm{M}]_{\text {org }}=\text { Metal concentration in the organic }
\end{aligned}
$$

$[\mathrm{M}]_{\mathrm{aq}}=$ Metal concentration in the aqueous phase $(\mathrm{mg} / \mathrm{L})$

\section{RESULTS AND DISCUSSIONS}

\section{Effect of Alamine $\mathbf{3 3 6}$ degradation}

In order to study the behavior of the solvent during the extraction process, Alamine 336 from two suppliers (Cognis and BASF) and Alamine 336 (Cognis) regenerated from the plant after several extraction cycles were investigated. The aqueous phase had uranium concentration of $3698 \mathrm{mg} / \mathrm{L}$ and $\mathrm{pH}=1$. The redox potential was $498 \mathrm{mV}$ and the organic phase had an Alamine 336 concentration of $0.1 \mathrm{M}$ in kerosene. The extraction was carried out in 5 contacts with an O/A ratio of 0.5 . The results are shown in Fig. 2. The solvent formed from Alamine 336 (Cognis and BASF) exhibited the same extraction behavior. Whereas, the regenerate solvent the uranium extraction decreased. Fig. 3 shown the total amount of uranium extracted with the 3 solvents after the 5 extraction cycles. The decrease of the extraction efficiency for the regenerated solvent may be due to the loss of Alamine 336 capacity to extract uranium. Indeed, according to Chagnes ${ }^{7}$ works on the improvement resistance of solvent degradation of COMINAK plant, Alamine 336 had tended to transform into secondary amine, primary amine and other compounds. This degradation was due to the presence of powerful 
oxidants in ore such as vanadium ${ }^{8}$ and chromium ${ }^{9}$. Abdoul-Rachid ${ }^{10}$ reported also that beyond $700 \mathrm{mV}$, Alamine 336 effectively extracted vanadium, which automatically caused the decrease of uranium extraction efficiency.

For following works Alamine 336 supplied by Cognis was used.

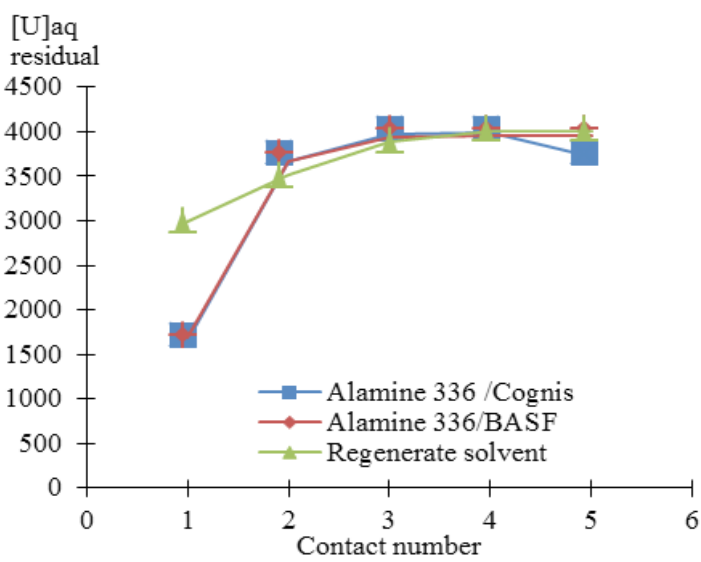

Fig. 2. Effect of Alamine 336 degradation on uranium extraction $(U=3698 \mathrm{mg} / \mathrm{L}$, Alamine $336=0.1 \mathrm{M}$, $\mathrm{O} / \mathrm{A}=1: 2, \mathrm{pH}=1, \mathrm{~T}=30^{\circ} \mathrm{C}, \mathrm{E}=498 \mathrm{mV}$, agitation: 700 rpm, mixing time: $2 \mathrm{~min}$ )

[U]org

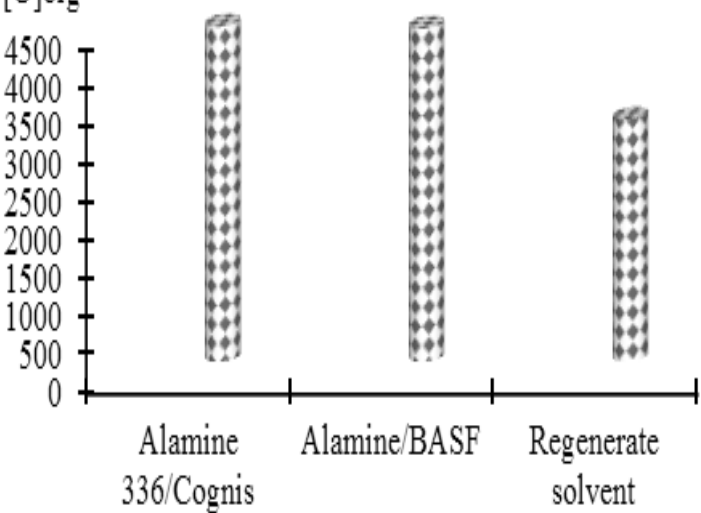

Fig. 3. Organic solvent charged after 5 cycles $(\mathrm{U}=3698 \mathrm{mg} / \mathrm{L}$, Alamine $336=0.1 \mathrm{M}, \mathrm{O} / \mathrm{A}=1: 2$, $\mathrm{pH}=1, \mathrm{~T}=30^{\circ} \mathrm{C}, \mathrm{E}=498 \mathrm{mV}$, agitation: $700 \mathrm{rpm}$, mixing time: 2 min)

Effect of contact number on uranium and molybdenum extraction from uranium bearing solutions

The contact number consists of maintaining a constant volume of organic and varying the volume of aqueous phase after each 2 min of agitation. The aqueous phase contained the following metals:
$\mathrm{U}=3698 \mathrm{mg} / \mathrm{L}, \mathrm{Mo}=65 \mathrm{mg} / \mathrm{L}, \mathrm{V}=2370 \mathrm{mg} / \mathrm{L}$ and $\mathrm{pH}=1$. The redox potential was $498 \mathrm{mV}$ and the free acidity was $\mathrm{H}^{+}=22 \mathrm{~g} / \mathrm{L}$. The organic phase had an Alamine 336 concentration of $0.1 \mathrm{M}$ in kerosene. The extraction was carried out in 5 contacts. Fig. 4 illustrates the effect of contact number on uranium extraction efficiency. Uranium extraction was effective at the first contact with $38 \%$. Molybdenum efficiency extraction decreased from $7 \%$ to the first contact to $3 \%$ at second contact. At $498 \mathrm{mV}$ Alamine 336 did not extract vanadium. The weak extraction efficiency may be due to these parameters low phase ratio $\mathrm{O} / \mathrm{A}$, sulfuric acid concentration of uranium bearing solutions.

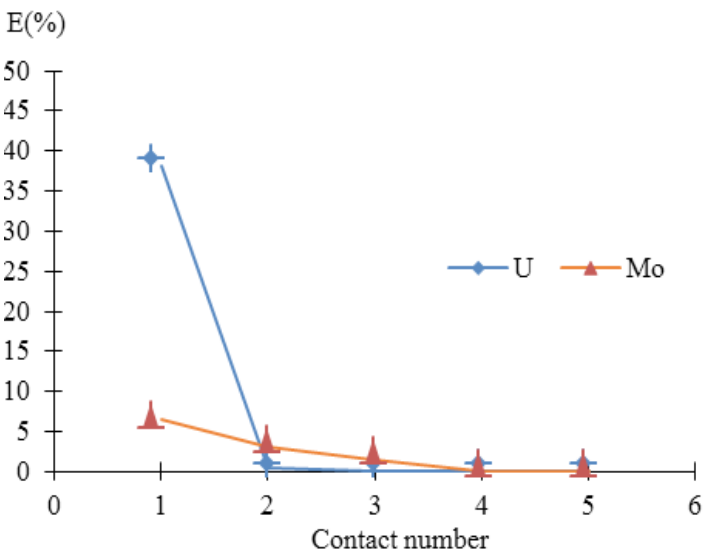

Fig. 4. Effect of contact number on uranium and molybdenum from uranium bearing solutions $(\mathrm{U}=3698 \mathrm{mg} / \mathrm{L}, \mathrm{Mo}=65 \mathrm{mg} / \mathrm{L}$, Alamine $336=0.1 \mathrm{M}$, $\mathrm{O} / \mathrm{A}=1: 2, \mathrm{pH}=1, \mathrm{~T}=30^{\circ} \mathrm{C}, \mathrm{E}=498 \mathrm{mV}$, agitation: $700 \mathrm{rpm}$, mixing time: $2 \mathrm{~min}$ )

\section{McCabe Thiele isotherm}

In order to obtain the optimal contact number for the extraction, McCabe Thiele isotherm was plotted. The aqueous phase had a uranium concentration of $3881 \mathrm{mg} / \mathrm{L}$. The free acidity was $\mathrm{H}^{+}=12 \mathrm{~g} / \mathrm{L}$ and redox potential was $498 \mathrm{mV}$. The organic phase had an Alamine 336 concentration of $0.1 \mathrm{M}$ in kerosene. The ratios $\mathrm{O} / \mathrm{A}$ were varied from $1: 2,1: 1,1.5: 1$ and 2:1. According, to results shown at Fig. 5. Two theoretical stages were required to extract efficiency uranium from uranium bearing solutions ${ }^{11}$. Collet ${ }^{12}$ studies on computer simulation and optimization of flow sheets reported also that with two feed inlets uranium could be recovery efficiency. 


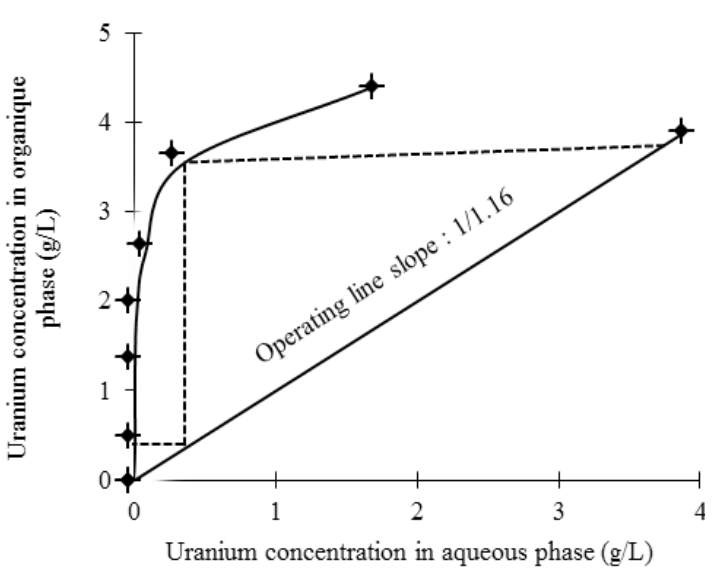

Fig. 5. Uranium extraction distribution isotherm

In order to increase the uranium extraction efficiency between the $1^{\text {st }}$ and $2^{\text {nd }}$ contact, parameters illustrated in section 3.4 to 3.7 were studied.

\section{Effect of the ratio of organic phase and aqueous phase}

The aqueous phase contained the following metals: $\mathrm{U}=3881 \mathrm{mg} / \mathrm{L}, \mathrm{Mo}=60 \mathrm{mg} / \mathrm{L}, \mathrm{V}=2370$ $\mathrm{mg} / \mathrm{L}$. The free acidity was $\mathrm{H}^{+}=12 \mathrm{~g} / \mathrm{L}$ and the redox potential was $496 \mathrm{mV}$. The organic phase had an Alamine 336 concentration of $0.1 \mathrm{M}$ in kerosene. The extraction was carried out in 2 contacts. The effect of O/A was shown at Fig. 6. The variation of ratio $\mathrm{O} / \mathrm{A}$ increased the uranium extraction efficiency from $39.47 \%$ up to $99.67 \%$ at the $1^{\text {st }}$ contact and from $5.16 \%$ up to $94 \%$ at the second contact.

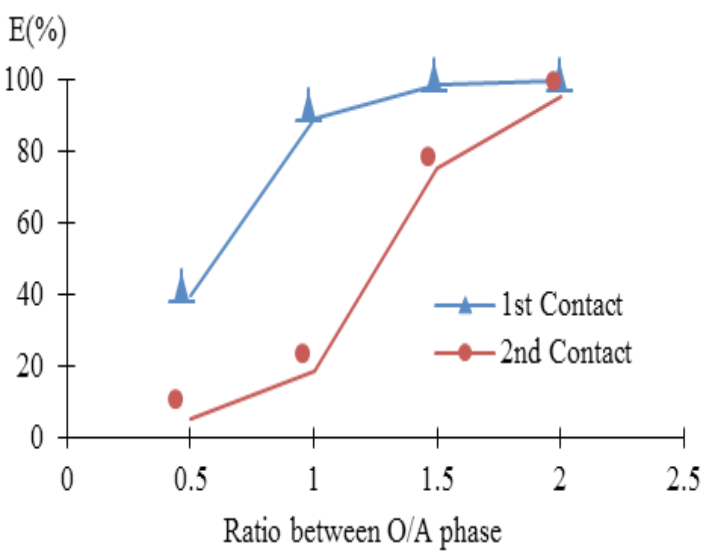

Fig. 6. Effect of ratio O/A on uranium extraction (Alamine $336=0.1 \mathrm{M}, \mathrm{pH}=1, \mathrm{~T}=30^{\circ} \mathrm{C}, \mathrm{E}=496 \mathrm{mV}$, agitation: 700 rpm, mixing time: $2 \mathrm{~min}$ )

\section{Effect of sulfuric acid concentration}

The aqueous phase contained the following metals: $\mathrm{U}=3619 \mathrm{mg} / \mathrm{L}, \mathrm{Mo}=50 \mathrm{mg} / \mathrm{L}, \mathrm{V}=2180$ $\mathrm{mg} / \mathrm{L}$. The free acidity was $\mathrm{H}^{+}=10 \mathrm{~g} / \mathrm{L}$ and the redox potential $500 \mathrm{mV}$. The organic phase had an
Alamine 336 concentration of $0.1 \mathrm{M}$ in kerosene. The ratio $\mathrm{O} / \mathrm{A}=1: 1$. The sulfuric acid concentration of uranium bearing solutions was varied from 0.1 to $1 \mathrm{~mol} / \mathrm{L}$. Fig. 7 illustrates the effect of sulfuric acid concentration on uranium extraction. For low sulfuric acid concentration (0.1-0.2) in the uranium bearing solutions, extraction efficiency increased from 88.91 up to $92 \%$ at the $1^{\text {st }}$ contact and from $18.42 \%$ up to $20 \%$ at the second contact. This enhancement of extraction efficiency may be due to $\mathrm{UO}_{2}\left(\mathrm{SO}_{4}\right)_{2}{ }_{2}$ - species which was majority in the solution at these range of concentrations. For lower sulfuric acid concentration uranium was in its $\mathrm{UO}_{2}\left(\mathrm{SO}_{4}\right)_{2}{ }_{2}$ - and $\mathrm{UO}_{2}\left(\mathrm{SO}_{4}\right)$ species in uranium bearing solutions ${ }^{13}$. In similar conditions $\left[\left(\mathrm{R}_{3} \mathrm{NH}\right)_{4} \mathrm{UO}_{2}\left(\mathrm{SO}_{4}\right)_{3}\right]$ complex was obtained during the extraction of $\mathrm{UO}_{2}\left(\mathrm{SO}_{4}\right)_{2}{ }_{2}$ by Alamine $336^{14-15}$.

The uranium extraction efficiency decreased when sulfuric acid concentrations were enhanced up to $0.2 \mathrm{M}$. Fig. 8 shown the diagram of the different uranium species present in strong sulfuric acid solutions ${ }^{16}$. Indeed, this drop of uranium extraction efficiency may be due to the different extraction mechanism because of the different speciation of uranium $\mathrm{UO}_{2}\left(\mathrm{SO}_{4}\right)_{2}^{2-}$ and $\mathrm{UO}_{2}\left(\mathrm{SO}_{4}\right)_{3}{ }^{4-}$ present in uranium bearing solutions. E.C Avelar ${ }^{17}$ studies on the modeling of the solvent extraction equilibrium of uranium reported that at higher concentration of sulfate ions $\mathrm{UO}_{2}\left(\mathrm{SO}_{4}\right)_{3}{ }^{4-}$ species were formed.

Therefore, the mechanisms of uranium extraction can described by the following equations:

$\left.\left[\left(\mathrm{R}_{3} \mathrm{NH}\right)_{2} \mathrm{SO}_{4}\right]_{\mathrm{org}}+\left[\mathrm{UO}_{2}\left(\mathrm{SO}_{4}\right)_{2}^{2-}\right)\right]_{\mathrm{aq}} \leftrightharpoons\left[\left(\mathrm{R}_{3} \mathrm{NH}\right)_{2}\right.$
$\left.\left.\mathrm{UO}_{2}\left(\mathrm{SO}_{4}\right)_{2}\right]_{\mathrm{org}}+\left[\mathrm{SO}_{4}^{2-}\right)\right]_{\mathrm{aq}}$
$\left.2\left[\left(\mathrm{R}_{3} \mathrm{NH}\right)_{2} \mathrm{SO}_{4}\right]_{\mathrm{org}}+\left[\mathrm{UO}_{2}\left(\mathrm{SO}_{4}\right)_{3}{ }_{3}^{4-}\right)\right]_{\mathrm{aq}} \leftrightharpoons\left[\left(\mathrm{R}_{3} \mathrm{NH}\right)_{4}\right.$
$\left.\left.\mathrm{UO}_{2}\left(\mathrm{SO}_{4}\right)_{3}\right]_{\mathrm{org}}+2\left[\mathrm{SO}_{4}^{2-}\right)\right]_{\mathrm{aq}}$

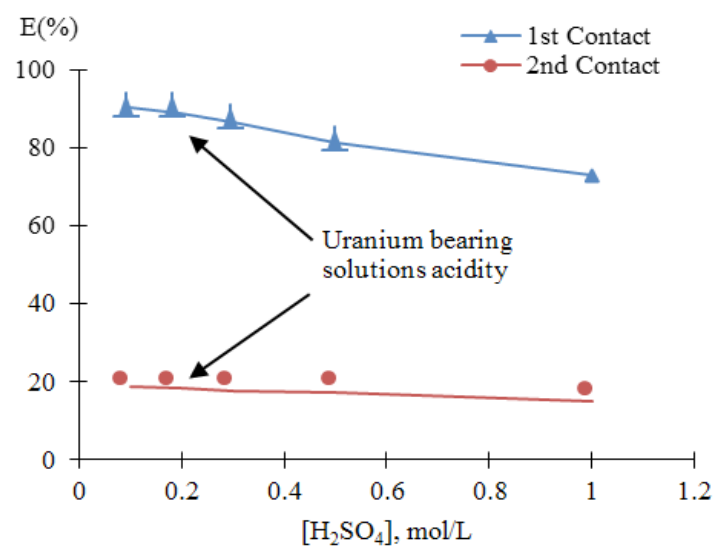

Fig. 7. Effect of sulfuric acid concentration on uranium extraction (Alamine $336=0.1 \mathrm{M}, \mathrm{T}=30^{\circ} \mathrm{C}$, $\mathrm{E}=500 \mathrm{mV}$, agitation: $700 \mathrm{rpm}$, mixing time: $2 \mathrm{~min}$ ) 


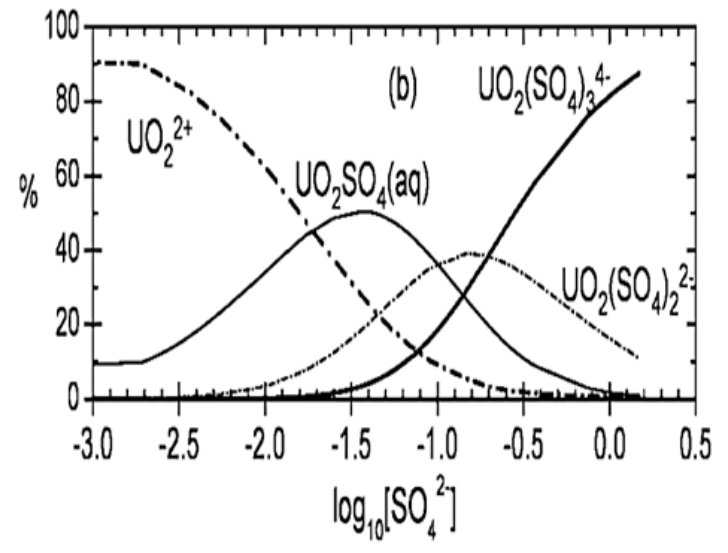

Fig. 8. Speciation diagram of uranium-sulfate-water system $^{17}$

\section{Effect of uranium concentration}

Various industrial solutions loaded with uranium were used. Barren liquor from the second filtration with $\mathrm{U}=450 \mathrm{mg} / \mathrm{L}$, production liquor from the first filtration with $U=1064 \mathrm{mg} / \mathrm{L}$, bearing solution with $\mathrm{U}=3619 \mathrm{mg} / \mathrm{L}$ and uranium bearing solution from storage tank with $\mathrm{U}=7112 \mathrm{mg} / \mathrm{L}$. The redox potential was $500 \mathrm{mV}$. The organic phase had an Alamine 336 concentration of $0.1 \mathrm{M}$ in kerosene. The ratio $\mathrm{O} / \mathrm{A}=1$ and the extraction was carried out in 2 contacts. Fig. 9 illustrates the results. The extraction was effective for uranium concentration of $1000 \mathrm{mg} / \mathrm{L}$ with efficiency percentage exceeding $90 \%$. The drop of the uranium percentage reflected the saturation of the complexing sites of Alamine 336. This saturation may be due to also to the $\left.\mathrm{UO}_{2}\left(\mathrm{SO}_{4}\right)_{3}{ }^{4}\right)$ speciation and 4 molecules of Alamine 336 complex one molecules of uranium sulfate according to the 1:4 stoichiometry ${ }^{18-19}$.

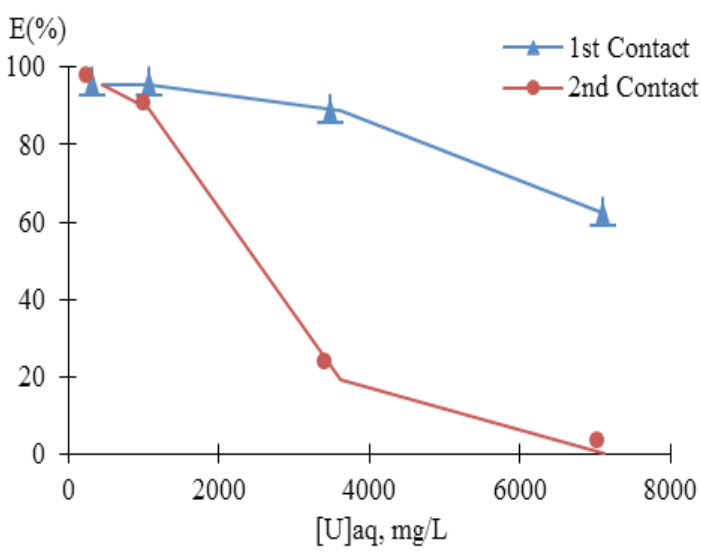

Fig. 9. Effect of uranium concentration variation (Alamine $336=0.1 \mathrm{M}, \mathrm{pH}=1, \mathrm{~T}=30^{\circ} \mathrm{C}, \mathrm{E}=500 \mathrm{mV}$, agitation: $700 \mathrm{rpm}$, mixing time: $2 \mathrm{~min}$ )
Effect of volume proportion of Alamine 336 in solvent formation

The aqueous phase contained the following metals: $\mathrm{U}=3619 \mathrm{mg} / \mathrm{L}, \mathrm{Mo}=50 \mathrm{mg} / \mathrm{L}, \mathrm{V}=2180 \mathrm{mg} / \mathrm{L}$. The redox potential was $500 \mathrm{mV}$ and the free acidity was $\mathrm{H}^{+}=10 \mathrm{~g} / \mathrm{L}$.

The proportion of Alamine 336, alcohol (Isotridecanol) and kerosene were varied and were illustrated in Table 3.

Table 3: Organic phase composition

\begin{tabular}{ccc}
\hline $\begin{array}{c}\text { Alamine 336 } \\
\text { percentage }\end{array}$ & $\begin{array}{c}\text { Isotridecanol } \\
\text { percentage }\end{array}$ & $\begin{array}{c}\text { Kerosene } \\
\text { percentage }\end{array}$ \\
\hline 2.5 & 3 & 94.5 \\
5 & 10 & 85 \\
7.5 & 3 & 89.5 \\
10 & 10 & 80 \\
\hline
\end{tabular}

The enhancement Fig.10 of Alamine 336 proportion in the organic phase formation increased the uranium extraction efficiency from $78.72 \%$ up to $99.58 \%$ at the first contact and from $4.61 \%$ up to $95.79 \%$ at the second contact. The addition of isotridecanol prevented the formation of a third phase. Zhu ${ }^{20}$ reported that using equal concentration percentage of isodecanol and Aliquat 336 eliminated the third phase formation.

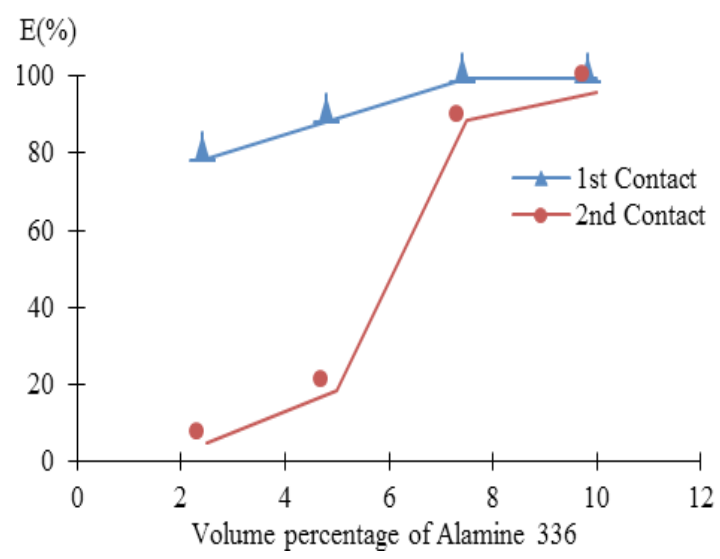

Fig.10. Effect of Alamine 336 volume proportion on uranium extraction (Alamine $336=0.1 \mathrm{M}, \mathrm{pH}=1, \mathrm{~T}=$ $30^{\circ} \mathrm{C}, \mathrm{E}=500 \mathrm{mV}$, agitation: $700 \mathrm{rpm}$, mixing time: $2 \mathrm{~min}$ )

\section{CONCLUSION}

The solvent extraction of uranium from sulfate liquor acid of Niger plant by Alamine 336 in kerosene modified with isotridecanol was investigated. The weak extractability of uranium was due to the degradation of Alamine 336, degradation 
caused by the presence of vanadium, which was an oxidant. According to McCabe Thiele isotherm, two theoretical stages were required to extract efficiency uranium. The variation of the O/A ratio from 0.5 to 2 had made it possible to recover more than $90 \%$ of uranium at the first contact. The variation in the $\mathrm{H}_{2} \mathrm{SO}_{4}$ concentration of the uranium liquor from 0.1 to 0.2 had also made it possible to recover more than $92 \%$ of uranium at first contact. For concentrations lower than $0.2 \mathrm{M}$ the species $\mathrm{UO}_{2}\left(\mathrm{SO}_{4}\right)_{2}^{2-}$ was predominant while for concentrations higher than $0.2 \mathrm{M}$ it had coexistence of the $\mathrm{UO}_{2}\left(\mathrm{SO}_{4}\right)_{2}{ }_{2}^{-}$and $\left.\mathrm{UO}_{2}\left(\mathrm{SO}_{4}\right)_{3}{ }^{4-}\right)$ species. The variation of the volume proportions of Alamine 336 and kerosene had made it possible to raise the uranium efficiency more than $98 \%$ with a volume percentage of Alamine 336 of 10 in the organic phase.

\section{ACKNOWLEDGEMENT}

The authors are thankful to director of Akouta Company COMINAK for his permission to do and publish this work.

\section{Conflicts of Interest}

The authors declare no conflict of interest.

\section{REFERENCES}

1. IAEA/OECD. Uranium Resources, Production and Demand. NEA No. 7413. Red Book., 2018, 317-326.

2. Billon, S. Clay minerals in uraniferous deposit of Imouraren (Tim Mersoï basin, Niger): implications on genesis of deposit and on ore treatment process. PhD Thesis, Poitiers University, France., 2014, 23-24. http://theses. univpoitiers.fr/notice/view/32762 [(04/11/20)].

3. Zhu, Z.; Cheng, C.Y. A review of uranium solvent extraction: its present status and future trends. ALTA 2011 Uranium Conference: $7^{\text {th }}$ Uranium Event, Australia., 2011, 215-220. https://www.altamet.com.au/wpcontent/ uploads/2013/07/ALTA-Uranium-2011Proceedings-Contents-Abstracts.pdf.

4. Munyungano, B.M. Solvent degradation-Rössing uranium mine. J. S. Afr. Inst. Min. Metall., SAIMM Conference., 2007, 107(7), 415-417.

5. Sole, K.C.; Cole, P.M.; Feather, A.M.; Kotze, M.H. Solvent extraction and ion exchange applications in Africa's resurging uranium industry: A review. Solvent Extr. Ion Exch., 2011, 29(5-6), 868-899. https://doi.org/10.1 080/07366299.2011.581101.

6. Chagnes, A.; Fosse, C.; Courtaud, B.; Thiry, J.; Cote, G. Chemical degradation of trioctylamine and 1-tridecanol phase modifier in acidic sulfate media in the presence of vanadium (V). Hydrometallurgy, 2011, 105(3-4), 328-333. https:// doi.org/10.1016/j.hydromet.2010.11.003.

7. Chagnes, A.; Courtaud, C.B.; Thiry, J. Improved resistance to degradation of the extraction solvent used at the Cominak plant (Niger). SEPA Report No. 2, Contract No.: DIR/2008-196, 2009.
8. Chagnes, A.; Courtaud, B.; Thiry, J.; Bayardon, J.; Jugé, S.; Cote, G. Influence of phase modifiers on the degradation of Tri-noctylamine/dodecane extracting mixture by an acidic solution of Vanadium (V). Solvent Extr. Ion Exch., 2012, 30(1), 67-76. https:// doi.org/10.1080/07366299.2011.566524.

9. Chagnes, A.; Cote, G. Chemical degradation of amixture of tri-n-octylamine and 1-tridecanol in the presence of chromium(VI) in acidic sulfate media. Metals., 2018, 8(1), 1-10. https://doi.org/10.3390/met8010057.

10. Abdoul-Rachid, C.Y.; Salmana, L.I.; Adamou, Z.; Ibrahim, N.; Ibrahim, M. Comparative study of solvent extraction of uranium with Alamine 336 and Aliquat 336: Application to the uranium-bearing solutions of Niger Republic. Eur. Sci. Journal, ESJ., 2018, 14(9), 76-92. https://doi.org/10.19044/esj.2018.v14n9p76

11. Chagnes, A.; Courtaud, B.; Thiry, J.; Cotea, G. Computer simulation of flow-sheets for the solvent extraction of uranium: A new route to delay the effect of chemical degradation of the organic phase during uranium recovery from acidic sulfate media. J. Chem. Technol. Biotechnol., 2009, 84(12),1899-1907. https:// doi.org/10.1002/jctb.2263.

12. Collet, S.; Chagnes, A.; Courtaud, B.; Thiry, J.; Cote, G. Solvent extraction of uranium from acidic sulfate media by Alamine $(336$ : Computer simulation and optimization of the flow-sheets. J. Chem. Technol. Biotechnol., 2009, 84(9), 1331-1337. https://doi.org/10.1002/jctb.2184.

13. Chagnes, A.; Courtaud, B.; Thiry, J. Formulation of a new extraction solvent for the Cominak plant (Niger). SEPA report, Contract. DIR/2011, 2011. 
14. Ramadevi, G.; Sreenivas, T.; Navale, A.S.; Padmanabhan, N.P.H. Solvent extraction of uranium from lean grade acidic sulfate leach liquor with alamine 336 reagent. J. Radioanal. Nucl. Chem., 2012, 294(1), 13-18. https://doi. org/10.1007/s10967-011-1507-y.

15. Jin-Young, L.; Jyothi, R. K.; Ho-Seok, J.; JoonSoo K. Extraction and separation of hexavalent molybdenum from acidic sulfate solutions using Alamine 336 as an extractant. Period. Polytech. Chem. Eng., 2010, 54(1), 27-31. https://doi.org/10.3311/pp.ch.2010-1.04.

16. Vercouter, T.; Vitorge, P.; Amekraz, B.; Moulin, C. Stoichiometries and thermodynamic stabilities for aqueous sulfate complexes of $\mathrm{U}(\mathrm{VI})$. Inorg. Chem., 2008. 47(6), 2180-2189. https://doi.org/10.1021/ic701379q.

17. Avelar, C.; Alvarenga, C.L.G.; Resende, G.P.S.; Morais, C.A.; Mansur, M.B. Modeling of the solvent extraction equilibrium of uranium $(\mathrm{VI})$ sulfate with Alamine 336. Brazilian J. Chem Eng., 2017, 34(1), 355-362. https://doi.org/1 0.1590/01046632.20170341s20150301.

18. Khanramaki, F.; Shirani, A.S.; Safdari, J.; Torkaman, R. Investigation of liquid extraction and thermodynamic studies on uranium from sulfate solution by Alamine 336 as an extractant. Int. J. Environ. Sci. Technol., 2018, 15(7), 1467-1476. https://doi.org/10.1007/ s13762-017-1473-1.

19. Zaheri, P.; Davarkhah, R. Selective separation of uranium from sulfuric acid media using a polymer inclusion membrane containing alamine 336. Chem. Pap., 2020, 1-9. https:// doi.org/10.1007/s11696-019-01029-9.

20. Zhu, Z.; Pranolo, Y.; Cheng, C.Y.Uranium solvent extraction and separation from Vanadium in alkaline solutions. Sep. Sci. Technol., 2013, 48(9), 1402-1408. https://doi.org/10.1080/014 96395.2012.738277 